\title{
Streptomyces emeiensis sp. nov., a novel streptomycete from soil in China
}

\author{
Correspondence \\ Ying Huang \\ huangy@im.ac.cn \\ Yue-Qin Zhang \\ zyq_0525@yahoo.com.cn
}

\author{
Wei Sun, ${ }^{1}$ Ying Huang, ${ }^{2}$ Yue-Oin Zhang $^{1}$ and Zhi-Heng Liu ${ }^{2}$ \\ ${ }^{1}$ The National Key Laboratory for Screening New Microbial Drugs, Institute of Medicinal \\ Biotechnology, Chinese Academy of Medical Sciences, Beijing 100050, \\ People's Republic of China \\ ${ }^{2}$ State Key Laboratory of Microbial Resources, Institute of Microbiology, Chinese Academy of \\ Sciences, Beijing 100101, People's Republic of China
}

\begin{abstract}
An actinomycete, strain $4776^{\top}$, was isolated from soil collected from Emei Mountain in Sichuan Province, China. The taxonomic status of this strain was established using a polyphasic approach. The organism was found to have morphological and chemotaxonomic characteristics typical of streptomycetes. Phylogenetic analysis based on the almost complete 16S rRNA gene sequence indicated that the novel isolate belongs to the genus Streptomyces and consistently falls into a clade together with Streptomyces prasinopilosus DSM $40098^{\top}$, Streptomyces prasinus JCM $4603^{\top}$, Streptomyces bambergiensis DSM 40590 ${ }^{\top}$, Streptomyces hirsutus DSM $40095^{\top}$ and Streptomyces cyanoalbus DSM 40198 ${ }^{\top}$. However, DNA-DNA relatedness and phenotypic data distinguished strain $4776^{\top}$ from these phylogenetically related type strains. It is therefore concluded that strain $4776^{\top}$ (=CGMCC $4.3504^{\top}=$ DSM $41884^{\top}$ ) represents a novel species of the genus Streptomyces, for which the name Streptomyces emeienseis sp. nov. is proposed.
\end{abstract}

Streptomycetes continue to be a rich source of novel bioactive, commercially significant compounds (Labeda et al., 1997; Dietera et al., 2003; Bérdy, 2005). Despite the large number of species with validly published names, the genus Streptomyces as a whole is underspeciated (Kim \& Goodfellow, 2002; Saintpierre et al., 2003; Huang et al., 2004; Xu et al., 2006). In the course of searching for new anti-atherosclerosis drugs targeted on the scavenger receptor BI (SR-BI), an active streptomycete-like strain, strain $4776^{\mathrm{T}}$, was isolated from a soil sample collected from Emei Mountain in Sichuan province, China. A polyphasic taxonomic investigation based on a judicious combination of genotypic and phenotypic characteristics revealed that the new isolate represents a novel species of the genus Streptomyces.

Strain $4776^{\mathrm{T}}$ was isolated after two weeks incubation at $28^{\circ} \mathrm{C}$ on yeast-malt extract agar (ISP 2; Shirling \& Gottlieb, 1966), which had been seeded with a soil sample suspension. The soil sample was collected from Emei Mountain, Sichuan, China. The isolate was maintained on ISP 2 slopes at $4{ }^{\circ} \mathrm{C}$ and as glycerol suspensions $(20 \%, \mathrm{v} / \mathrm{v})$ at $-20^{\circ} \mathrm{C}$. Biomass for molecular systematic and most of the chemotaxonomic

Abbreviation: SEM, Scanning electron microscopy.

The GenBank/EMBL/DDBJ accession number for the 16S rRNA gene sequence of strain $4776^{\top}$ is DQ462649.

Light and scanning electron micrographs showing the spore-chain morphology and spore-surface ornamentation of cells of strain $4776^{\top}$ are available with the online version of this paper. studies was obtained after incubation in shake flasks of ISP 2 broth at $28^{\circ} \mathrm{C}$ for $4-7$ days.

The spore-chain morphology and spore-surface ornamentation of strain $4776^{\mathrm{T}}$ were recorded by examining goldcoated dehydrated specimens of 10 to 14-day cultures grown on ISP 2 agar by scanning electron microscopy (SEM) (Quanta; FEI). The coverslip technique (Zhou et al., 1998; Kawato \& Shinobu, 1959) was used to observe the hyphae and spore-chain characteristics. Aerial spore-mass colour, substrate mycelial pigmentation and the production of diffusible pigments were estimated on a number of agar media (Table 1) following incubation at $28^{\circ} \mathrm{C}$ for 14 days.

The isomers of diaminopimelic acid and whole-cell sugar composition were analysed by TLC following procedures described by Hasegawa et al. (1983) and Lechevalier \& Lechevalier (1980). Menaquinones were extracted and determined using the methods of Collins (1985). The phospholipid analysis was carried out using the technique described by Minnikin et al. (1984). The fatty acids were extracted, methylated and estimated by GC using the standard Sherlock MIDI (Microbial Identification) system (Sasser, 1990; Kämpfer \& Kroppenstedt, 1996). The G+C content of genomic DNA was determined using the thermal denaturation method of Marmur \& Doty (1962) with Escherichia coli $\mathrm{K} 12$ as a control.

Strain $4776^{\mathrm{T}}$ was examined for a broad range of biochemical and physiological characteristics according to the 
Table 1. Comparison of cultural characteristics of strain $4776^{\top}$ and Streptomyces prasinopilosus DSM $40098^{\top}$

No soluble pigments were produced on the listed agars.

\begin{tabular}{|c|c|c|c|c|}
\hline \multirow[t]{2}{*}{ Agar medium } & \multicolumn{2}{|c|}{ Aerial mycelium } & \multicolumn{2}{|c|}{ Substrate mycelium } \\
\hline & Strain $4776^{\mathrm{T}}$ & DSM $40098^{T}$ & Strain $4776^{\mathrm{T}}$ & DSM $40098^{T}$ \\
\hline Czapek Dox & $\begin{array}{l}\text { Strong yellowish green; } \\
\text { abundant }\end{array}$ & Yellowish green; moderate & $\begin{array}{l}\text { Greyish yellowish } \\
\text { brown }\end{array}$ & Dark yellow \\
\hline Glycerol-asparagine (ISP 5) & Green; abundant & Green; moderate & Yellow & Greyish yellow \\
\hline Inorganic salts-starch (ISP 4) & Greyish green; abundant & Pinkish white; abundant & Brown & Strong reddish orange \\
\hline Oatmeal (ISP 3) & Greyish green; moderate & $\begin{array}{c}\text { Deep yellow-green; } \\
\text { moderate }\end{array}$ & Dark brown & Dark yellow \\
\hline Peptone-yeast extract-iron (ISP 6) & White; abundant & None & Brown & Not distinctive \\
\hline Yeast extract-malt extract (ISP 2) & Dark green; abundant & Greyish green; moderate & Dark brown & Light yellow \\
\hline Yeast extract-starch & $\begin{array}{l}\text { Dark greyish olive; } \\
\text { abundant }\end{array}$ & Green & Dark brown & Pinkish yellow \\
\hline Modified Bennett's & Olive green; abundant & Greyish green; moderate & Sudan brown & Dark brown \\
\hline Santou's & White; abundant & White; moderate & Dark brown & Greyish greenish yellow \\
\hline
\end{tabular}

established methods of Williams et al. (1983) and Kämpfer et al. (1991). Tolerance to temperature and $\mathrm{pH}$ was tested on ISP 2 agar plates incubated for 7-14 days. Resistance to antibiotics was examined as described by Al-Tai et al. (1999). Readings were taken at 1, 3, 7 and 14 days and inhibition zones observed were scored as negative.

Isolation of chromosomal DNA and PCR amplification of the 16S rRNA gene were carried out after Chun \& Goodfellow (1995). Sequencing of the PCR product was performed as described by $\mathrm{Gu}$ et al. (2006). The resultant sequence was aligned manually using CLUSTAL_X version 1.8 (Thompson et al., 1997) with available, almost complete sequences of type strains of the family Streptomycetaceae and then with corresponding sequences of representative species of the genus Streptomyces. Phylogenetic trees were constructed using the least-squares (Fitch \& Margoliash, 1967), maximum-likelihood (Felsenstein, 1981), maximum-parsimony (Fitch, 1971) and neighbour-joining (Saitou \& Nei, 1987) algorithms from the PHYLIP package version $3.5 \mathrm{c}$ (Felsenstein, 1993) and the TREECON program version 1.3b (Van de Peer \& De Wachter, 1994). Evolutionary distance matrices were generated according to the method of Kimura (1980). Tree topologies were evaluated by performing bootstrap analysis based on 1000 resamplings of the neighbourjoining dataset using the SEQBOOT and CONSENSE programs provided in the PHYLIP package (Felsenstein, 1993).

Levels of DNA-DNA relatedness between strain $4776^{\mathrm{T}}$ and related type strains were determined using the fluorometric micro-well method (Ezaki et al., 1989), with the modifications described by He et al., (2005).

The chemical and morphological properties of strain $4776^{\mathrm{T}}$ were consistent with its assignment to the genus Streptomyces (Williams et al., 1989; Manfio et al., 1995). The organism formed an extensively branched substrate mycelium, aerial hyphae which carried spiny-surfaced spores in rectiflexibiles and hooked spore chains (Fig. 1) and a greenish aerial spore mass on various standard media (Table 1). The novel strain contained LL-diaminopimelic acid in whole-organism hydrolysates, hexa-, octa- and a minor amount of tetra-hydrogenated menaquinones with nine isoprene units [MK-9 $\left(\mathrm{H}_{6}, \mathrm{H}_{8}\right.$ and $\left.\left.\mathrm{H}_{4}\right)\right]$ as isoprenologues and phosphatidylethanolamine and phosphatidylinositol and phosphatidylinositol mannosides as the major polar lipids (phospholipid type II sensu Lechevalier et al., 1977), but lacked characteristic sugars and mycolic acids. The fatty acid profile included mainly saturated iso- and anteiso-branched-chain and straight-chain fatty acids (fatty acid type 2c sensu Kroppenstedt, 1985).

The almost complete 16S rRNA gene sequence (1400 nt) was determined for strain $4776^{\mathrm{T}}$. The sequence data clearly showed that strain $4776^{\mathrm{T}}$ is a member of genus Streptomyces.

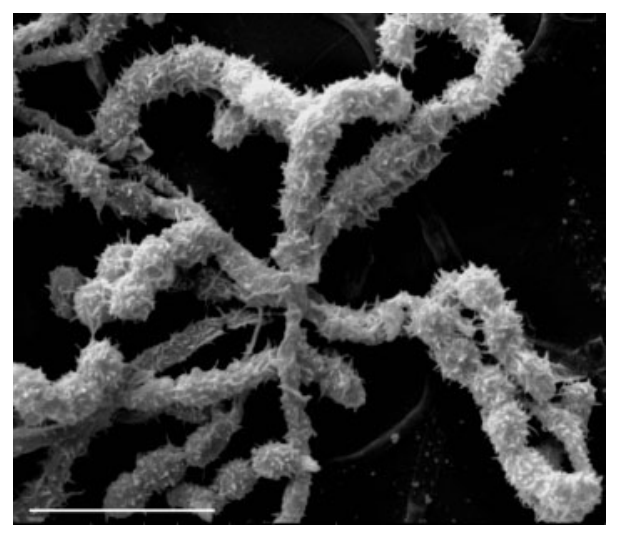

Fig. 1. Scanning electron micrograph showing spore chains and spore-surface ornamentation of cells of Streptomyces emeiensis sp. nov. $4776^{\top}$ grown on yeast-malt extract agar (ISP 2) for 14 days at $28^{\circ} \mathrm{C}$. Bar, $2.5 \mu \mathrm{m}$. 


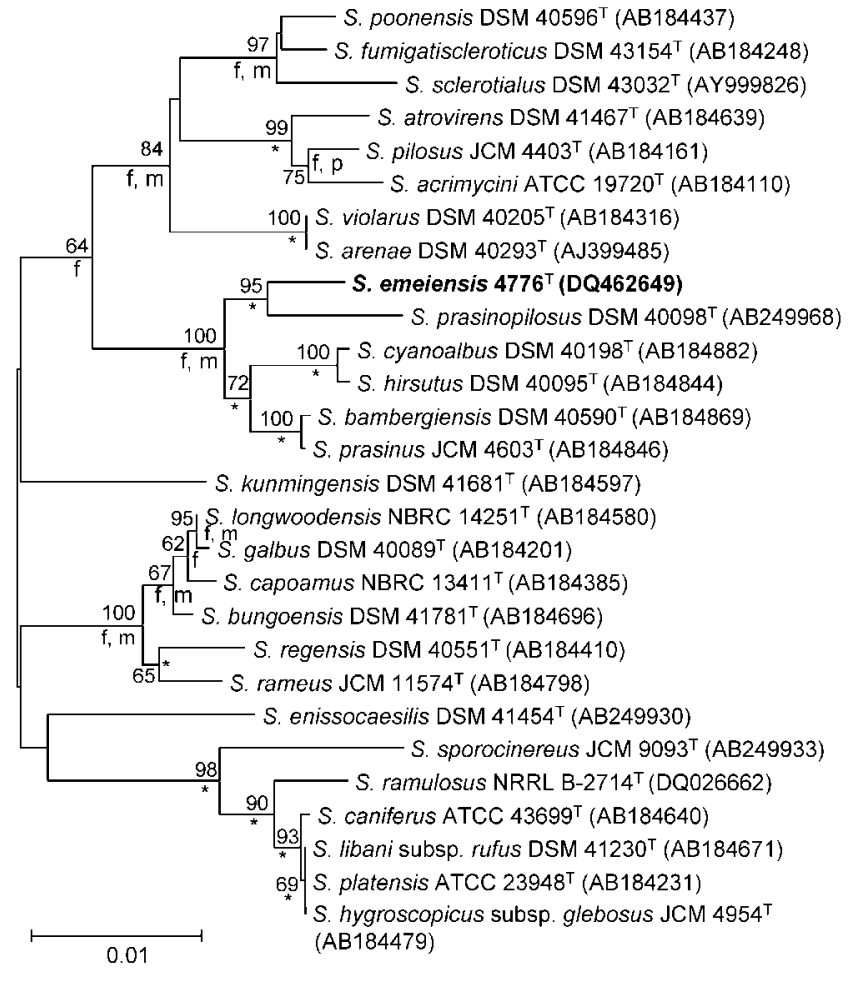

Fig. 2. Unrooted neighbour-joining tree (Saitou \& Nei, 1987) based on 16S rRNA gene sequences showing the phylogenetic relationship between strain $4776^{\top}$ and related species of the genus Streptomyces. Asterisks refer to branches that were recovered using all four tree-making algorithms. $f, m$ and $p$, respectively indicate branches that were also formed using the Fitch-Margoliash (Fitch \& Margoliash, 1967), maximumlikelihood (Felsenstein, 1981) and maximum-parsimony (Fitch, 1971) tree-making algorithms. Numbers at nodes indicate levels of bootstrap support (\%) based on a neighbour-joining analysis of 1000 resampled datasets; only values above $50 \%$ are given. Bar, 0.01 substitutions per nucleotide position.

It was evident from Fig. 2 that strain $4776^{\mathrm{T}}$ formed a distinct phyletic line with Streptomyces prasinopilosus DSM $40098^{\mathrm{T}}$. This line was supported by all four tree-making algorithms and by a high bootstrap value. Three tree-making algorithms and a $100 \%$ bootstrap value supported the position that the strain $4776^{\mathrm{T}}-$ S. prasinopilosus line was consistently in the same clade along with Streptomyces prasinopilosus DSM $40098^{\mathrm{T}}$, Streptomyces prasinus JCM $4603^{\mathrm{T}}$, Streptomyces bambergiensis DSM $40590^{\mathrm{T}}$, Streptomyces hirsutus DSM $40095^{\mathrm{T}}$ and Streptomyces cyanoalbus DSM $40198^{\mathrm{T}}$. $16 \mathrm{~S}$ rRNA gene sequence similarities between strain $4776^{\mathrm{T}}$ and these type strains were between 98.6 and $98.8 \%$ (1819 nucleotide differences at 1390-1402 sites). The novel isolate showed the shortest phylogenetic distance (0.012) with S. prasinopilosus DSM $40098^{\mathrm{T}}$ and S. prasinus JCM $4603^{\mathrm{T}}$, although it showed a lower $16 \mathrm{~S}$ rRNA gene sequence identity with $S$. prasinopilosus DSM $40098^{\mathrm{T}}$ than with the other four neighbours from the BLAST result. This is probably because the $16 \mathrm{~S}$ rRNA gene sequence of $S$. prasinopilosus that has been deposited in the GenBank database is shorter than those of the other species and contains more gaps (4 gaps).

DNA-DNA hybridization tests were carried out between strain $4776^{\mathrm{T}}$ and the phylogenetically close type strains. The DNA-DNA relatedness between strain $4776^{\mathrm{T}}$ and S. prasinopilosus DSM $40098^{\mathrm{T}}(62.7 \%)$, S. prasinus JCM $4603^{\mathrm{T}}$ (55.5\%), S. hirsutus DSM $40095^{\mathrm{T}}$ (46.4\%), S. bambergiensis DSM $40590^{\mathrm{T}}(31.7 \%)$ and S. cyanoalbus DSM $40198^{\mathrm{T}}$ (26.1\%) are all well below the $70 \%$ cut-off point generally recognized for genomic species (Wayne et al., 1987), thus suggesting that the novel strain should be considered as a separate species. Comparison of the phenotypic characteristics of strain $4776^{\mathrm{T}}$ and its close phylogenetic neighbours also revealed significant differences (Table 2). S. prasinopilosus was selected for a detailed cultural characteristic comparison with strain $4776^{\mathrm{T}}$ on the basis of phylogenetic distance and DNA-DNA relatedness data and its close position to the novel isolate in all four phylogenetic trees. Despite the resemblance borne by the two strains, the two strains could be differentiated by several characteristics (Table 1), especially when using ISP 4, ISP 6 and yeast extract-starch agars.

A combination of genotypic and phenotypic data show that strain $4776^{\mathrm{T}}$ merits recognition as the type strain of a novel species in the genus Streptomyces, for which we propose the name Streptomyces emeiensis sp. nov.

\section{Description of Streptomyces emeiensis sp. nov.}

Streptomyces emeiensis (e.mei.en'sis. N.L. masc. adj. emeiensis pertaining to Emei, a famous mountain in Sichuan Province, southern China, where the sample yielding the type strain was collected).

Aerobic, mesophilic, Gram-positive actinomycete that develops well-branched substrate and aerial mycelium. Diffusible pigments are not formed, nor are melanin pigments produced on peptone/yeast extract/iron or tyrosine agars. Additional cultural characteristics on various agar media are shown in Table 1. Rectiflexibiles and hooked spore chains of elliptic, spiny-surfaced spores are frequently arranged in a verticillate structure. Growth occurs between 15 and $40{ }^{\circ} \mathrm{C}$ and at $\mathrm{pH}$ values from 5.5 to 9.5 , but not at $\mathrm{pH} 4.5$ or 10.5 . Growth occurs in the presence of $0.1 \%$ phenol (w/v), $5 \% \mathrm{NaCl}(\mathrm{w} / \mathrm{v})$ and $0.01 \% \mathrm{NaN}_{3}(\mathrm{w} / \mathrm{v})$, but not in the presence of $7 \% \mathrm{NaCl}(\mathrm{w} / \mathrm{v})$. Nitrate is reduced. Amylase and gelatinase are not produced. Shows weak antimicrobial activity against strains of Bacillus subtilis and Mycobacterium smegmatis, but not against strains of Staphylococcus epidermidis, Escherichia coli, Klebsiella pneumoniae, Pseudomonas aeruginosa or Candida albicans. The organism is sensitive to filter-paper discs soaked in the following $\left(\mu \mathrm{g} \mathrm{ml}^{-1}\right)$ : novobiocin (5), streptomycin (10), oxacillin (1), chloramphenicol (30), ciprofloxacin (5) and erythromycin (15). Additional physiological properties 
Table 2. Phenotypic characteristics of strain $4776^{\top}$ and related species of the genus Streptomyces

Strains: 1, strain $4776^{\mathrm{T}}$; 2, S. bambergiensis DSM 40590 ${ }^{\mathrm{T}}$; 3, S. cyanoalbus DSM 40198 ${ }^{\mathrm{T}}$; 4, S. hirsutus DSM 40095 ${ }^{\mathrm{T}}$; 5, S. prasinopilosus DSM $40098^{\mathrm{T}}$; 6, S. prasinus DSM 40099 ${ }^{\mathrm{T}}$. All strains degrade Tween 60, Tween 80 and elastin. All are negative for degradation of xanthine, hypoxanthine and guanine and are positive for the assimilation of galactose, glucose, D-sucrose, D-fructose, D-mannose, D-cellobiose, D-trehalose, L-rhamnose, D-xylose and sodium citrate. Melanin production of all strains is negative. +, Positive; - , negative; $(+)$, weakly positive; RA, retinaculiaperti; RF, rectiflexibiles; SP, spiral.

\begin{tabular}{|c|c|c|c|c|c|c|}
\hline Characteristic & 1 & 2 & 3 & 4 & 5 & 6 \\
\hline Aerial spore mass on oatmeal agar & Greyish green & Green & Green or grey & Green & Green & Green \\
\hline Spore chain & RF \& hooked & SP & SP & $\mathrm{RA}$ to $\mathrm{SP}$ & RA & RA to $S P$ \\
\hline Spore surface & Spiny & Hairy & Spiny & Spiny & Hairy & Spiny \\
\hline Production of diffusible pigments & - & + & - & - & - & - \\
\hline \multicolumn{7}{|c|}{ Growth on sole carbon sources $(1.0 \%, \mathrm{w} / \mathrm{v})$ : } \\
\hline L-Arabinose & + & $(+)$ & + & + & + & + \\
\hline L-Phenylalanine & + & - & $(+)$ & + & + & + \\
\hline L-Cysteine $(0.1 \%)$ & - & + & + & + & + & + \\
\hline D-Sorbose & - & + & + & + & + & + \\
\hline D-Ribose & + & - & - & - & - & - \\
\hline Methyl $\alpha$-D-glucopyranoside & - & - & + & $(+)$ & $(+)$ & + \\
\hline D-Melezitose & + & - & $(+)$ & + & - & + \\
\hline myo-Inositol & + & + & + & + & - & + \\
\hline D-Raffinose & + & + & - & + & - & - \\
\hline Inulin & - & + & + & + & + & + \\
\hline L-Valine $(0.1 \%)$ & - & + & + & + & + & + \\
\hline Dextrin & + & + & + & - & + & + \\
\hline Sodium malonate $(0.1 \%)$ & - & - & - & - & + & - \\
\hline Sodium acetate $(0.1 \%)$ & - & - & + & - & - & - \\
\hline \multicolumn{7}{|l|}{ Degradation of: } \\
\hline Adenine & + & - & + & - & - & - \\
\hline Aesculin & + & - & + & + & + & - \\
\hline Tween 20 & + & $(+)$ & + & + & + & + \\
\hline Tween 40 & + & - & + & + & + & + \\
\hline
\end{tabular}

are listed in Table 2. The cell-wall is of type I. Type II phospholipids and menaquinone $\mathrm{MK}-9\left(\mathrm{H}_{6}, \mathrm{H}_{8}\right.$ and $\left.\mathrm{H}_{4}\right)$ are detected. The fatty acid profile is composed of anteiso- $\mathrm{C}_{15: 0}$ $(14.6 \%)$, iso- $\mathrm{C}_{16: 0}(13.3 \%)$, anteiso- $\mathrm{C}_{17: 0}(12.6 \%), \mathrm{C}_{16: 0}$ $(9.4 \%), \mathrm{C}_{16: 1} \omega 7 c(8.2 \%)$, anteiso- $\mathrm{C}_{17: 1} \omega 9 c(7.0 \%), \mathrm{C}_{18: 0}$ $(3.7 \%), \mathrm{C}_{17: 1} \omega 8 c(3.6 \%)$, iso $\mathrm{H}-\mathrm{C}_{16: 1}(3.6 \%), \mathrm{C}_{15: 0}$ $(3.1 \%)$, iso- $\mathrm{C}_{15: 0}(3.0 \%)$, iso- $\mathrm{C}_{17: 1} \omega 9 c(3.0 \%)$, iso- $\mathrm{C}_{15: 0}$ $(3.0 \%), \mathrm{C}_{14: 0}(2.8 \%), \mathrm{C}_{18: 1} \omega 9 c(2.4 \%), \mathrm{C}_{18: 1} \omega 7 c(1.6 \%)$, iso- $\mathrm{C}_{17: 0}(1.3 \%), \mathrm{C}_{17: 0}(1.1 \%)$, iso- $\mathrm{C}_{14: 0}(1.1 \%)$ and iso I$\mathrm{C}_{15: 1}(1.1 \%)$. The $\mathrm{G}+\mathrm{C}$ content of the DNA is $70.8 \mathrm{~mol} \%$.

The type strain, strain $4776^{\mathrm{T}}$ (= CGMCC $4.3504^{\mathrm{T}}=\mathrm{DSM}$ $41884^{\mathrm{T}}$ ), was isolated from a soil sample collected from Emei Mountain, Sichuan Province, China.

\section{Acknowledgements}

This research was supported by National Facilities and Information Infrastructure for Science and Technology (grant number 2005DKA21203) and Natural Science Foundation of China (NSFC, grant number 30670002).

\section{References}

Al-Tai, A., Kim, B., Kim, S. B., Manfio, G. P. \& Goodfellow, M. (1999). Streptomyces malaysiensis sp. nov., a new streptomycete species with rugose, ornamented spores. Int J Syst Bacteriol 49, $1395-1402$.

Bérdy, J. (2005). Bioactive microbial metabolites. J Antibiot (Tokyo) 58, $1-26$.

Chun, J. \& Goodfellow, M. (1995). A phylogenetic analysis of the genus Nocardia with $16 \mathrm{~S}$ rRNA gene sequences. Int J Syst Bacteriol 45, 240-245.

Collins, M. D. (1985). Isoprenoid quinone analysis in classification and identification. In Chemical Methods in Bacterial Systematics, pp. 267-287. Edited by M. Goodfellow \& D. E. Minnikin. London: Academic Press.

Dietera, A., Hamm, A., Fiedler, H.-P., Goodfellow, M., Müller, W. E. G., Brun, R., Beil, W. \& Bringmann, G. (2003). Pyrocoll, an antibiotic, antiparasitic and antitumor compound produced by a novel alkalophilic Streptomyces strain. J Antibiot (Tokyo) 56, 639-646.

Ezaki, T., Hashimoto, Y. \& Yabuuchi, E. (1989). Fluorometric deoxyribonucleic acid-deoxyribonucleic acid hybridization in microdilution wells as an alternative to membrane filter hybridization in 
which radioisotopes are used to determine genetic relatedness among bacterial strains. Int J Syst Bacteriol 39, 224-229.

Felsenstein, J. (1981). Evolutionary trees from DNA sequences: a maximum likelihood approach. J Mol Evol 17, 368-376.

Felsenstein, J. (1993). PHYLIP (phylogeny inference package), version 3.5c. Distributed by the author. Department of Genome Sciences, University of Washington, Seattle, USA.

Fitch, W. M. (1971). Toward defining the course of evolution: minimum change for a specific tree topology. Syst Zool 20, 406-416.

Fitch, W. M. \& Margoliash, E. (1967). Construction of phylogenetic trees: a method based on mutation distances as estimated from cytochrome $c$ sequences is of general applicability. Science 155, 279284.

Gu, Q., Luo, H., Zheng, W., Liu, Z. \& Huang, Y. (2006). Pseudonocardia oroxyli sp. nov., a novel actinomycete isolated from the surface-sterilized Oroxylum indicum root. Int J Syst Evol Microbiol 56, 2193-2197.

Hasegawa, T., Takizawa, M. \& Tanida, S. (1983). A rapid analysis for chemical grouping of aerobic actinomycetes. J Gen Appl Microbiol 29, 319-332.

He, L., Li, W., Huang, Y., Wang, L., Liu, Z. H., Lanoot, B., Vancanneyt, M. \& Swings, J. (2005). Streptomyces jietaisiensis sp. nov., isolated from soil in northern China. Int J Syst Evol Microbiol 55, 1939-1944.

Huang, Y., Li, W., Wang, L., Lanoot, B., Vancanneyt, M., Rodriguez, C., Liu, Z., Swings, J. \& Goodfellow, M. (2004). Streptomyces glauciniger sp. nov., a novel mesophilic streptomycete isolated from soil in south China. Int J Syst Evol Microbiol 54, 2085-2089.

Kämpfer, P. \& Kroppenstedt, R. M. (1996). Numerical analysis of fatty acid patterns of coryneform bacteria and related taxa. Can J Microbiol 42, 989-1005.

Kämpfer, P., Kroppenstedt, R. M. \& Dott, W. (1991). A numerical classification of the genera Streptomyces and Streptoverticillium using miniaturized physiological tests. J Gen Microbiol 137, 1831-1891.

Kawato, M. \& Shinobu, R. (1959). On Streptomyces herbaricolor sp. nov., supplement: a single technique for microscopical observation. Mem Osaka Unit Lib Arts Educ B Nat Sci 8, 114-119.

Kim, S. B. \& Goodfellow, M. (2002). Streptomyces avermitilis sp. nov., nom. rev., a taxonomic home for the avermectin-producing streptomycetes. Int J Syst Evol Microbiol 52, 2011-2014.

Kimura, M. (1980). A simple method for estimating evolutionary rates of base substitutions through comparative studies of nucleotide sequences. J Mol Evol 16, 111-120.

Kroppenstedt, R. M. (1985). Fatty acid and menaquinone analysis of actinomycetes and related organisms. In Chemical Methods in Bacterial Systematics, pp. 173-199. Edited by M. Goodfellow \& D. E. Minnikin. London: Academic Press.

Labeda, D. P., Lechevalier, M. P. \& Testa, R. T. (1997). Streptomyces stramineus sp. nov., a new species of the verticillate streptomycetes. Int J Syst Bacteriol 47, 747-753.

Lechevalier, H. A. \& Lechevalier, M. P. (1980). The chemotaxonomy of actinomycetes. In Actinomycete Taxonomy, Special Publication no. 6, pp. 277-284. Edited by A. Dietz \& D. W. Thayer. Arlington, VA: Society of Industrial Microbiology.
Lechevalier, M. P., De Bièvre, C. \& Lechevalier, H. A. (1977). Chemotaxonomy of aerobic actinomycetes: phospholipid composition. Biochem Syst Ecol 5, 249-260.

Manfio, G. P., Zakrzewska-Czerwinska, J., Atalan, E. \& Goodfellow, M. (1995). Towards minimal standards for the description of Streptomyces species. Biotekhnologiia 8, 228-237.

Marmur, J. \& Doty, P. (1962). Determination of base composition of deoxyribonucleic acid from its denaturation temperature. J Mol Biol 5, 109-118.

Minnikin, D. E., O'Donnell, A. G., Goodfellow, M., Alderson, G., Athalye, M., Schaal, A. \& Parlett, J. H. (1984). An integrated procedure for the extraction of isoprenoid quinones and polar-lipids. J Microbiol Methods 2, 233-241.

Saintpierre, D., Amir, H., Pineau, R., Sembiring, L. \& Goodfellow, M. (2003). Streptomyces yatensis sp. nov., a novel bioactive streptomycete isolated from a New-Caledonian ultramafic soil. Antonie van Leeuwenhoek 83, 21-26.

Saitou, N. \& Nei, M. (1987). The neighbour-joining method: a new method for reconstructing phylogenetic trees. Mol Biol Evol 4, 406-425.

Sasser, M. (1990). Identification of Bacteria by Gas Chromatography of Cellular Fatty Acids. Technical Note 101. Newark, DE: Microbial ID.

Shirling, E. B. \& Gottlieb, D. (1966). Methods for characterization of Streptomyces species. Int J Syst Bacteriol 16, 313-340.

Thompson, J. D., Gibson, T. J., Plewniak, F., Jeanmougin, F. \& Higgins, D. G. (1997). The CLUSTAL_X windows interface: flexible strategies for multiple sequence alignment aided by quality analysis tools. Nucleic Acids Res 25, 4876-4882.

Van de Peer, Y. \& De Wachter, R. (1994). TREECON for windows: a software package for the construction and drawing of evolutionary trees for the Microsoft Windows environment. Comput Appl Biosci 10, 569-570.

Wayne, L. G., Brenner, D. J., Colwell, R. R., Grimont, P. A. D., Kandler, O., Krichevsky, M. I., Moore, L. H., Moore, W. E. C., Murray, R. G. E. \& other authors (1987). International Committee on Bacterial Systematics. Report of the ad hoc committee on reconciliation of approaches to bacterial systematics. Int J Syst Bacteriol 37, 463-464.

Williams, S. T., Goodfellow, M., Alderson, G., Wellington, E. M. H., Sneath, P. H. A. \& Sackin, M. J. (1983). Numerical classification of Streptomyces and related genera. J Gen Microbiol 129, 1743-1813.

Williams, S. T., Goodfellow, M. \& Alderson, G. (1989). Genus Streptomyces Waksman and Henrici 1943, 339 ${ }^{\mathrm{AL}}$. In Bergey's Manual of Systematic Bacteriology, vol. 4, pp. 2594-2598. Edited by S. T. Williams, M. E. Sharpe \& J. G. Holt. Baltimore: Williams \& Wilkins.

Xu, C., Wang, L., Cui, O., Huang, Y., Liu, Z., Zheng, G. \& Goodfellow, M. (2006). Neutrotolerant acidophilic Streptomyces species isolated from acidic soils in China: Streptomyces guanduensis sp. nov., Streptomyces paucisporeus sp. nov., Streptomyces rubidus sp. nov. and Streptomyces yanglinensis sp. nov. Int J Syst Evol Microbiol 56, 1109-1115.

Zhou, Z. H., Liu, Z. H., Qiao, Y. D., Kim, S. B. \& Goodfellow, M. (1998). Saccharopolyspora spinosporotrichia sp. nov., a novel actinomycete from soil. Int J Syst Bacteriol 48, 53-58. 